\title{
Distribution, MORPHOlOgY, SURVIVAL, AND GENETICS OF ASPEN (POPULUS TREMULOIDES) SEEDLINGS FOLLOWING THE 1988 YELLOWSTONE FIRES
}

\author{
MONICA G. TURNER $\downarrow$ REBECCA A. REED \\ UNIVERSITY OF WISCONSIN $\downarrow$ MADISON \\ WILLIAM H. ROMME $\downarrow$ FORT LEWIS COLLEGE \\ DURANGO $\downarrow \mathrm{CO}$ \\ GERALD A. TUSKAN $\downarrow$ OAK RIDGE NATIONAL LABORATORY \\ $\mathrm{OAK}$ RIDGE $\downarrow$ TN
}

\section{$\downarrow \quad$ INTRODUCTION}

An unexpected consequence of the 1988 Yellowstone fires was the widespread establishment of seedlings of quaking aspen (Populus tremuloides) in the burned forests, including areas outside the previous range of aspen (Kay 1993; Romme et al. 1997). Although aspen is the most widely distributed tree species in North America (Fowells 1965), it is relatively uncommon and localized in distribution within Yellowstone National Park (Despain 1991). Most aspen stands in Yellowstone are found in the lower elevation landscapes in the northern portion of the park, and the species was absent -- prior to 1988 -- across most of the high plateaus that dominate the southern and central park area. Aspen in the Rocky Mountain region reproduces primarily by means of vegetative root sprouting. Although viable seeds are regularly produced, establishment of seedlings in the wild is apparently a rare event due to the limited tolerance of aspen seedlings for desiccation or competition (e.g., Pearson 1914; McDonough 1985). In the immediate aftermath of the 1988 Yellowstone fires, there was a brief "window of opportunity" for aspen seedling establishment, as a result of abundant aspen seed production, moist weather conditions in spring and summer, and bare mineral soil and reduced plant competition within extensive burned areas (Jelinski and Cheliak 1992; Romme et al. 1997).

We initiated this 3-year study in 1996 to address four questions about the aspen seedlings now growing in burned areas across the Yellowstone Plateau: (1) What are the broad-scale patterns of distribution and abundance of aspen seedlings across the subalpine plateaus of Yellowstone National Park? (2) What is the morphology and population structure - e.g., proportions of genets (genetic individuals that developed from a single seed) and ramets (vegetative root sprouts produced by a genet) of various ages -- in aspen seedling populations? (3) What are the mechanisms leading to eventual persistence or extirpation of seedling populations along an elevational gradient, particularly with respect to ungulate browsing and plant competition? (4) What is the genetic diversity and relatedness of 
the seedling populations along gradients of elevation and substrate?

\section{$\downarrow \quad$ METHODS}

We addressed the first question (broad-scale patterns of distribution and abundance) by sampling distances of 1 - $17 \mathrm{~km}$ along 18 foot trails distributed throughout the burned portions of the subalpine plateaus within Yellowstone National Park (Table 1a). We counted the number of aspen seedlings within 2 meters on either side of the trail, and also recorded details of elevation, aspect, slope, and fire severity (unburned, lethal [stand-replacing] burn, or non-lethal burn in 1988) for each $10-500$ meter segment of the trail. The trailside data were analyzed using logistic regression and ANOVA, which enabled us to develop predictions of aspen seedling occurrence and density as functions of burn status (burned vs unburned), elevation, substrate, topographic position, and geographic location within the park (Reed et al. 1997a). We also established small permanent plots 20 meters off the trail every few kilometers, and measured aspen seedling density, height, and basal diameter within these plots. The plots will be re-measured annually for at least the next 2 years to document survival and growth under a range of conditions of elevation, topographic position, substrate, and browsing intensity. Finally, we flew over the subalpine plateaus of southern, western, and central Yellowstone National Park in September, 1996, and mapped the locations of all visible adult aspen stands (conspicuous at that time of year because of yellow leaves) that could be potential parents of the seedlings.

For the second question, we excavated aspen seedlings and associated ramets at five study areas across the subalpine plateaus of Yellowstone National Park (Table 1b). At two of these study areas, we completely removed 20 individuals by carefully excavating along the roots. These sampled individuals were measured in the field (stem length, maximum root length and depth, number of ramets), then returned to the lab where they were dried and weights of roots and shoots determined. In the other three study areas, we mapped all of the aspen stems within an area of 50 $300 \mathrm{~m}^{2}$. We then partially excavated each stem to detect physical connections between stems (ramets), but did not remove plants from the ground. For each stem we determined age (from bud scale scars) and number of ramets, and we collected a small leaf sample for genetic analysis (Reed et al. 1997b).

We used an experimental approach to investigate mechanisms of persistence or extirpation of aspen seedlings (question \#3). At each of three different locations within burned forests (Table 1c), we fenced 13 small plots $\left(100-500 \mathrm{~m}^{2}\right)$ to exclude ungulates, by means of double-stranded wire attached to standing fire-killed trees. In each plot we mapped 12 - 24 aspen seedlings (to allow remeasurement of the same plants in future years) and measured plant height, basal diameter, age, and number of leaves in late August, 1996. These plants will be re-measured annually for at least the next two years to detect responses to the experimental treatments. Experimental treatments at each of the three locations included: clipping of aspen plants to simulate elk browsing ( 3 plots); removal of lodgepole pine and herbaceous plants within 1 meter of the measured aspen plants by means of cutting and herbicide, to remove potential plant competitors (3 plots); clipping plus removal of competitors (3 plots); and no clipping or competitor removal (3 plots). In the 13th plot we pruned several individual aspen seedlings and removed local competitors to see if we could induce growth into tree form (most of the aspen seedlings are now growing in a shrublike form, with several branches arising low on the main stem and a maximum height of only $0.5-1.0$ meter).

To investigate the genetic structure of the aspen seedling populations (question \#4), we collected small discs from young leaves at the five locations where seedling morphology and population structure were sampled (Table 1b) and in the permanent plots associated with the trailside surveys (Table 1a). We also collected leaf discs from several adult aspen clones representing possible seed sources of the aspen seedlings on the subalpine plateaus. These adult clones were located around the margins of the Yellowstone Plateau, or in unusual habitats upon the plateau (cliffs, talus slopes, and lake shores having a southern exposure). The leaf samples were returned to the laboratory and analyzed by means of RAPD -- a "DNA fingerprinting" technique (Tuskan et al. 1996). 
Table 1. Locations of aspen seedling study areas in Yellowstone National Park (see text for details).

a. Trailside surveys

Cascade/Grebe/Wolf Lake

Cygnet Lakes

Two Ocean Plateau

Two Ocean Plateau spur

Lewis River Channel

Pitchstone Plateau
Riddle Lake

Shoshone Lake

Mount Homes

Heart lake

Mallard Creek

Mallard Lake
Fern Cascades

Little Firehole Meadows

Outlet Creek

Trail Creek

Summit Lake

Harlequin Lake

b. Morphology and population structure

near Mallard Creek trailhead (excavation)

near Old Faithful water treatment plant (excavation)

near Fern Cascades (mapping and excavation)

near western end of Old Fountain Trail (mapping)

near Lewis Lake (mapping)

c. Mechanisms of persistence or extirpation

Fountain site: near western end of Old Fountain trail (low elevation ... within pre1988 range of aspen)

Fern site: near Fern Cascades (mid elevation ... outside pre-1988 range of aspen)

Lewis site: near Heart Lake trailhead (high elevation ... outside pre-1988 range of aspen)

\section{$\downarrow \quad$ RESULTS}

Analysis of the trailside aspen seedling data revealed that aspen seedlings were present only in areas that had burned in 1988 . Within burned areas, the best predictors of aspen seedling presence and abundance were: elevation (higher probability of presence and higher density at lower elevations), distance to nearest adult aspen (higher probability and density at shorter distances), geographic region of the park (highest probability and density in the south-central and southwestern regions), and the interaction between elevation and distance. Using these relationships and the geographic data-bases within a GIS environment (GRASS), we developed a map of Yellowstone National Park showing predicted seedling densities throughout the burned areas (Reed et al. 1997a), and will test these predictions with additional trailside surveys during subsequent field seasons.
Within the five study areas where aspen seedling morphology and population structure was examined (Table 1b), the majority of stems (58\%) had originated in 1989 or 1990 (Reed et al. 1997b). The proportion of stems originating in each year from 1989 to 1996 decreased in an approximately negative exponential curve. Most stems were individual genets; we found few physical connections between stems (12 out of 157 sampled stems), and genetic analysis showed distinctive genotypes in most individuals. Mean maximum root length ranged from $31-122 \mathrm{~cm}$. The plants were shallowly rooted, with mean maximum root depths of $13-29 \mathrm{~cm}$. Total plant weights were $1.8-6.2$ grams, and the mean proportion of plant biomass allocated to roots ranged from $33-43 \%$.

We measured the plants within the experimental plots (Table 1c) in late August, 1996, but will not perform analyses on these data until the plants are re-sampled in 1997. Genetic samples were collected, but analyses are not yet complete. 


\section{DISCUSSION}

We have taken advantage of a rare "natural experiment" -- the 1988 Yellowstone fires -- to investigate the responses of plant populations to large, infrequent disturbances. The results of this study may provide insights into likely effects on wildland ecosystems of other kinds of stresses and disturbances in the future, e.g., global climate change or altered fire regimes (Graham et al. 1990, Romme and Turner 1991). For long-lived, clonal plant species like aspen, either vegetative reproduction via root sprouting or sexual reproduction via seedling establishment may be effective for local re-establishment after disturbance. However, only seedling establishment is effective for long-distance dispersal and for broad-scale shifts in distribution of the species (Eriksson 1992) -- as may be necessary in the face of future climate change or habitat alteration in the northern Rocky Mountain region.

The results of this current study have verified some earlier ideas about the aspen seedlings that became established after the 1988 Yellowstone fires, e.g., that seedlings are restricted to burned areas, that they are most abundant in the westcentral and southwestern portions of the park, and that most germinated within the first two years after the fires (Romme et al. 1997). However, the more detailed observations and analyses that we completed in 1996 have revised some of those earlier ideas. For example, we found that a low level of seedling establishment probably continued for several years after the fires rather than being confined to the first two years (cf. Kay 1993), that few of the new aspen genets have produced ramets, and that seedling density is significantly correlated with elevation and distance to potential seed source as well as geographic region.

Two key questions remain unanswered: (1) Will the new aspen genets that established on the subalpine plateaus after the 1988 fires persist and effectively expand the range of aspen beyond what it was before 1988? Or will they succumb to ungulate browsing, competition from developing new stands of lodgepole pine, climatic constraints, or a combination of these factors, and gradually disappear from the Yellowstone landscape with no long-lasting ecological effects? (2) Where did the seeds come from that germinated to produce the aspen seedlings now growing outside the pre-1988 range of the species? Do the parents have a tree-like morphology or are they shrubs? Do the seedlings and their parents represent a broad spectrum of genetic diversity, or a limited sample of genotypes? Will genetic makeup be an important predictor of the ultimate survival or extinction of individual aspen seedlings across the Yellowstone landscape?

It may be many years before we have final answers to these questions. However, the long-term experimental plot studies and the genetic studies that we initiated in 1996 will help us understand the structure and dynamics of the aspen seedling populations, as well as the ecological mechanisms (e.g., ungulate browsing and plant competition) that will determine their eventual roles in the Yellowstone landscape.

\section{ACKNOWLEDGMENTS}

Financial support for this research was provided by the USDA competitive grants program and the University of Wisconsin. The UW-NPS Research Center and Yellowstone National Park provided invaluable logistic support. We thank our field assistants -- Jeff Cardille, Yvonne Corcoran, Jamie Corcoran, Mark Dixon, Jeffrey Erwin, Jennifer Fraterigo, Lee Gunter, Jesse McAfee, David Melkonian, Josie Plaut, Michael Stevens, Dan Tinker, and Patrick Whitmore -- for their hard work, diligence, and willingness to take on any task.

\section{$\downarrow \quad$ LITERATURE CITED}

Despain, D. G. 1991. Yellowstone vegetation. Consequences of environment and history in a natural setting. Roberts Rinehart Publishers, Boulder, CO

Erikssen, O. 1992. Evolution of seed dispersal and recruitment in clonal plants. Oikos 63:439448.

Fowells, H. A. 1965. Silvics of forest trees of the United States. USDA Agricultural Handbook Number 271, Washington, D.C.

Graham, R. L. 1990. How increasing atmospheric $\mathrm{CO} 2$ and climate change affects forests. BioScience 40:575-587. 
Jelinski, D. E., and W. M. Cheliak. 1992. Genetic diversity and spatial subdivision of Populus tremuloides (Salicaceae) in a heterogeneous landscape. American Journal of Botany 79:728-736.

Kay, C. E. 1993. Aspen seedlings in recently burned areas of Grand Teton and Yellowstone National Parks. Northwest Science 67:94-104.

McDonough, W. T. 1985. Sexual reproduction, seeds and seedlings. Pages 25-33, in: DeByle, N. V., and R. P. Winokur, Aspen ecology and management in the western United States. USDA General Technical Report RM-119.

Pearson, G. A. 1914. The role of aspen in the reforestation of mountain burns in Arizona and New Mexico. Plant World 17:249-260.

Reed, R. A., M. G. Turner, W. H. Romme, and G. A. Tuskan. 1997a. Post-fire aspen seedling recruitment across the Yellowstone landscape. Submitted to Ecology.
Reed, R. A., W. H. Romme, G. A. Tuskan, and M. G.Turner.1997b.Clonal structure and root morphology in post-fire aspen seedling populations on the Yellowstone plateau. Submitted to Canadian Journal of Botany.

Romme, W. H., and M. G. Turner. 1991. Implications of global climate change for biogeographic patterns in the Greater Yellowstone Ecosystem. Conservation Biology 5:373-386.

Romme, W. H., M. G. Turner, R. H. Gardner, W. W. Hargrove, G. A. Tuskan, D. G. Despain, and R. A. Renkin. 1997. A rare episode of sexual reproduction in aspen (Populus tremuloides) following the 1988 Yellowstone fires. Natural Areas Journal 17:17-25.

Tuskan, G. A., K. E. Francis, S. L. Russ, W. H. Romme, and M. G. Turner. 1996. RAPD markers reveal diversity within and among clonal and seedling stands of aspen in Yellowstone National Park, U.S.A. Canadian Journal of Forest Research 26:2088-2098. 